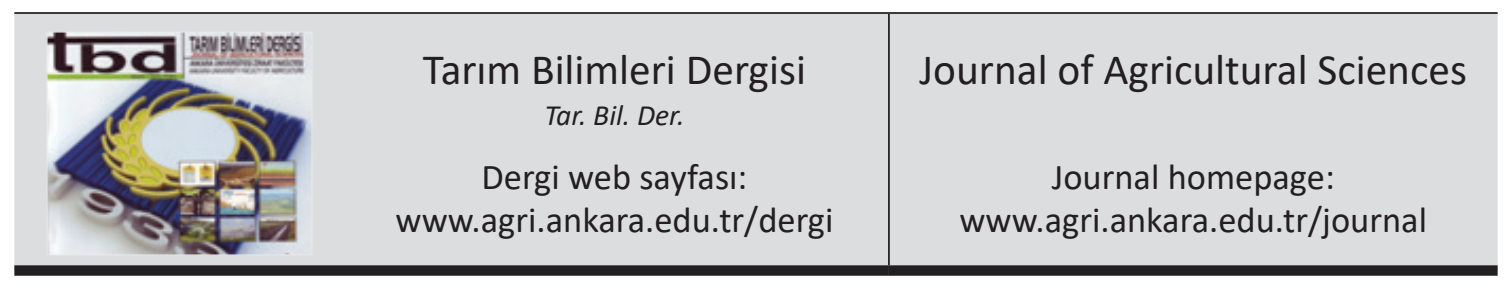

\title{
Genetic Effects Assessment through Line $\times$ Tester Combining Ability for Development of Promising Hybrids Based on Quantitative Traits in Gossypium hirsutum L.
}

\author{
Khadijah MAKHDOOM ${ }^{a}$, Naqib Ullah KHAN ${ }^{a *}$, Shahid Ullah KHAN ${ }^{b}$, Samrin GUL ${ }^{a}$, Zarina BIBIc, \\ Rozina GUL ${ }^{a}$, Sardar ALI ${ }^{d}$, Naushad ALI ${ }^{d}$, Shah Masaud KHAN ${ }^{d}$ \\ ${ }^{a}$ Department of Plant Breeding and Genetics, The University of Agriculture, Peshawar, PAKISTAN \\ ${ }^{b}$ Institute of Biotechnology and Genetic Engineering (IBGE), The University of Agriculture, Peshawar, PAKISTAN \\ ${ }^{c}$ Institute of Soil and Environmental Sciences, Faculty of Agriculture, Gomal University, Dera Ismail Khan, PAKISTAN \\ ${ }^{d}$ Department of Agricultural Sciences, University of Haripur, Haripur, PAKISTAN
}

\section{ARTICLE INFO}

Research Article DOI: 10.15832 ankutbd.538997

Corresponding Author: Naqib Ullah KHAN, E-mail: nukmarwat@yahoo.com, Tel: +92 (346) 9019112

Received: 17 September 2017, Received in Revised Form: 15 November 2017, Accepted: 14 March 2018

\begin{abstract}
Line $\times$ Tester combining ability analysis involving five lines (cultivars i.e., CIM-446, CIM-473, CIM-506, CIM-554 and SLH-284) and three testers (cultivars viz., CIM-496, CIM-499 and CIM-707) was carried out during 2015 and 2016 to determine the inheritance for earliness, yield and lint traits in upland cotton. Genotypes revealed significant $(\mathrm{P} \leq 0.01)$ variations for all the traits. On average, $\mathrm{F}_{1}$ hybrids showed the significant increase over parental means for yield traits. Mean squares due to general (GCA) and specific combining ability (SCA) were highly significant, which suggested that additive and non-additive gene actions were involved in controlling all the characters. However, the preponderance of non-additive type of gene action observed for majority of the traits. Lines (SLH-284, CIM-473) and pollinators (CIM-707, CIM-496) were leading general combiners for majority of the traits. $\mathrm{F}_{1}$ hybrids (CIM-473 $\times$ CIM-496, SLH-284 $\times$ CIM-707 and CIM$446 \times$ CIM-496) which involve best general combiners, showed the leading performance for yield and lint traits. Heritability was moderate to high with appreciable genetic gain for majority of the traits. Except for lint $\%$, the correlation of seed cotton yield was positive with other traits. The significance of additive and non-additive components suggested integrated breeding strategies with delayed selection for development of cotton hybrids with improvement in earliness and seed cotton yield.

Keywords: Combining ability; General and specific combiners; Additive and nonadditive gene action; Earliness and yield traits; Upland cotton
\end{abstract}

(C) Ankara Üniversitesi Ziraat Fakültesi

\section{Introduction}

In Pakistan, the cotton research work has been started since independence and a large number of cultivars acquiring harmonious combination of characters were evolved. Nevertheless, our per unit seed cotton yield is still low as compared to other cotton growing countries. In 2017-18, the cotton crop was grown on 2.699 million hectares and seed cotton production was 11.935 million bales $(170 \mathrm{~kg})$ with average seed cotton yield of $752 \mathrm{~kg} \mathrm{ha}^{-1}$ (PBS 
2017-2018). Cotton production showed remarkable growth of $12.3 \%$ to 11.935 million bales over 20162017 production (10.671 million bales) (Economic Survey of Pakistan 2017-2018). Pakistan is facing a problem of low production as compared to other cotton growing countries. One of the main causes of low productivity is inferior cotton genotypes being grown in the country. To cope-up with the present level of production, it is imperative to develop new high yielding cultivars/hybrids with higher yield potential along with early maturity, desirable fiber quality and natural resistance to insect pests and diseases up to some extent.

Line $\times$ tester combining ability analysis is an appropriate breeding approach for choosing desirable parental genotypes and $\mathrm{F}_{1}$ hybrids. General combining ability (GCA) is defined as average performance of a genotype in a series of cross combinations while specific combining ability (SCA) connotes those instances where certain hybrids are either better or poorer than would be expected on average performance in specific hybrid combinations (Usharani et al 2016). Thus, the SCA is important for hybrid crop development, whereas the GCA is useful for identification of potential parental genotypes for hybridization and then selection in segregating population. However, GCA is due to parental genes which are largely additive in nature, while SCA is due to new gene complexes with dominance or epistatic effects (Sprague \& Tatum 1942). In addition, in combining ability the maternal effects were also explored (Griffing 1956). Later on the line $\times$ tester analysis was designed which is an extension to the said method in which several lines and testers are used to predict the GCA and SCA of genotypes and their $F_{1}$ cross combinations, respectively (Kempthorne 1957; Singh \& Chaudhary 1985).

Combining ability of the inbred lines has been worked-out in cotton crop but most of the times the results remained discordant. Since the development of new cultivars through hybridization is a time consuming and continuous process, therefore information on the potentiality of new inbred lines through combining ability analysis becomes an important objective of the cotton breeders. Significance of the GCA and SCA variances, suggesting the importance of additive as well as dominant genes, nevertheless in their studies, ratio of GCA/SCA was greater than unity further indicating the preponderance of additive genes in the inheritance of seed cotton yield, bolls per plant, boll weight, seed index and lint $\%$ in cotton (Abro et al 2009; Basal et al 2009; Prakash et al 2018). However, appreciable degree of variance due to GCA was observed for these characters in upland cotton (Khan et al 2011; 2015). Contrary to above findings, the GCA and SCA variances were important yet the magnitude of SCA was higher than GCA implying the predominance of dominant genes controlling number of bolls, seed cotton yield, ginning outturn $\%$ and seed index (Panhwar et al 2008; Khan et al 2009a; Sivia et al 2017; Bilwal et al 2018; Roy et al 2018). Non-additive type of gene action for various earliness, morphological and yield related traits was observed in upland cotton populations (Khan et al 2017; Kumar et al 2017; Reddy et al 2017; Khokhar et al 2018). These controversial findings might be primarily due to mating designs, breeding material used, and the environment in which the breeding material was evaluated.

Mean squares due to GCA and SCA were also highly significant; however, the SCA variances were greater than GCA and more important for boll weight, boll number and seed cotton yield per plant, showing the predominance of non-additive gene action in cotton (Khan et al 2009b; Karademir et al 2016; Talpur et al 2016; Choudhary et al 2017; Lokesh et al 2018; Rajeev \& Patil 2018). In some studies, high $\times$ low and low $\times$ high GCA parents performed well in SCA determination in upland cotton (Khan et al 2011). Mean squares due to GCA and SCA were highly significant, however, GCA mean squares were higher than SCA for majority traits which revealed that additive genes controlled the inheritance in upland cotton (Khan et al 2015). Many commercial cotton cultivars despite their high/low agronomic performance combine in a better way/poorly when used as a parental cultivars in cross combinations. 
Heritability and the genetic variability studies of various genotypes in form of their expression for different morpho-yield traits are earnestly needed for selection of parental lines for breeding program. Knowledge about the genetic potential of different genotypes and inheritance of the morphological and yield traits is indispensable for the breeders to tackle with the problems of low yield (Khan et al 2009b; Thombre et al 2018). Substantial genetic variances and high heritability estimates implied that characters could be improved through selection from segregating populations. Heritability estimates sense were generally found to be high in magnitude in the G. hirsutum crosses comparative to G. barbadense L. for majority traits except for earliness and fiber \% (Esmail 2007).

In view of the importance of knowing the combining ability of the parental genotypes, thereby determining the type of gene action involved in the expression of various plant characters in cotton, the line $\times$ tester analysis along with heritability and correlation studies was carried out to determine the efficient breeding strategies to improve the valuable characters. The objectives behind this research work were to determine a) genetic variability of parental lines, testers and their $F_{1}$ hybrids for earliness and yield traits, b) GCA of lines/testers and SCA of L $\times$ $\mathrm{T}$ interactions for various traits, c) best general and specific combiners, which could be used as a source material for further improvement in upland cotton.

\section{Material and Methods}

\subsection{Breeding material and procedure}

Present investigations were carried out during 2015 and 2016 at the University of Agriculture,

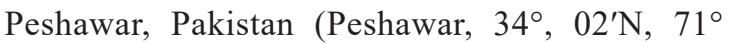
and $37^{\prime} \mathrm{E}$, Pakistan). Five upland cotton cultivars i.e. CIM-446, CIM-506, CIM-554, SLH-284 and CIM-473 were used as lines/female parents and three cultivars i.e., CIM-496, CIM-499 and CIM-707 as testers/pollinators (Table 1). These genotypes were hand sown in a crossing block during 2015, and were crossed through line $\times$ tester $(5 \times 3)$ methodology to make $15 \mathrm{~F}_{1}$ crosses. During 2016, 23 genotypes (08 parents and 15 $\mathrm{F}_{1}$ hybrids) were hand sown in a randomized complete block (RCB) design. Each Parent and $\mathrm{F}_{1}$ hybrid was planted in four rows of five meter length, with three replications. The rows and plants spacing were 75 and $30 \mathrm{~cm}$, respectively. Thinning was practiced after two weeks days when the plants gained the height of around 10 $\mathrm{cm}$ to ensure single plant per hill. Recommended cultural practices like fertilizer, hoeing, irrigation and pest control were applied uniformly to all the entries in order to minimize the environmental variations in the field. Picking was made during the month of November on individual plant basis and ginning was performed with eight saw-gins.

Table 1- Eight diverse genotypes of upland cotton used in $5 \times 3$ line $\times$ tester crosses

\begin{tabular}{llccccc}
\hline Cultivars & Parentage & Breeding centre & $\begin{array}{c}\text { Release } \\
(\text { year })\end{array}$ & $\begin{array}{c}\text { Seed cotton } \\
\text { yield }(\mathrm{kg} \mathrm{ha})\end{array}$ & $\begin{array}{c}\text { GOT } \\
(\%)\end{array}$ & $\begin{array}{c}\text { Staple length } \\
(\mathrm{mm})\end{array}$ \\
\hline Lines & & & & & \\
\hline CIM-446 & CP-15/2 $\times$ S-12 & CCRI, Multan, Pakistan & 1998 & 3,000 & 36.1 & 27.0 \\
CIM-473 & CIM-402 $\times$ LRA-5166 & -do- & 2002 & 3,000 & 39.7 & 29.5 \\
CIM-506 & CIM-360 $\times$ CP-15/2 & -do- & 2004 & 3,000 & 38.6 & 28.7 \\
CIM-554 & 2579-04/97 $\times$ W-1103 & -do- & 2009 & 4,241 & 41.5 & 28.5 \\
SLH-284 & Not yet released & CRS, Sahiwal, Pakistan & - & 3,707 & 39.0 & 28.5 \\
\hline Testers & & & & & & \\
\hline CIM-496 & CIM-425 $\times 755-6 / 93$ & CCRI, Multan, Pakistan & 2005 & 3,000 & 41.1 & 29.7 \\
CIM-499 & CIM-433 $\times 755-6 / 93$ & -do- & 2003 & 3,000 & 40.0 & 29.6 \\
CIM-707 & CIM-243 $\times 738-6 / 93$ & - do- & 2004 & 3,000 & 39.0 & 32.2 \\
\hline
\end{tabular}

Tarım Bilimleri Dergisi - Journal of Agricultural Sciences 


\subsection{Traits measurement and data analysis}

Data were recorded on ten randomly selected plant in central two rows on earliness (days to flowering), bolls per sympodia, bolls per plant, boll weight, seed cotton yield per plant and lint $\%$. All the data were subjected to analysis of variance to test the null hypothesis of no differences among various $F_{1}$ hybrids and their parental cultivars (Steel et al 1997). The genotype means for each parameter were further separated and compared by using the least significant difference (LSD) test at 5\% level of probability (Hayter 1986). Line $\times$ Tester analysis was carried out to ascertain the variances due to GCA and SCA for genotypes and gene action for various traits (Kempthorne 1957; Singh \& Chaudhary 1985). For each trait the genetic, environmental and phenotypic variances, broad sense heritability and expected response to selection $(\mathrm{Re})$ and its value as percentage were estimated according from the mean squares (Burton 1951). The correlation coefficient (r) of seed cotton yield with earliness and yield contributing traits was also worked out (Kwon \& Torrie 1964).

\section{Results and Discussion}

Analysis of variance revealed significant $(\mathrm{P} \leq 0.01)$ variations among parental genotypes (lines and testers) and their $\mathrm{F}_{1}$ hybrids ( $\mathrm{L} \times \mathrm{T}$ interactions) for all the traits except lint $\%$ for which the mean differences were merely significant $(\mathrm{P} \leq 0.05)$ (Table 2). This provides evidence of sufficient genetic variability among lines, testers, and $\mathrm{F}_{1}$ hybrids and allows further assessment through combining ability analysis. The total genetic variability was further partitioned into its components i.e., GCA and SCA. Past studies also revealed highly significant differences among line, testers and $\mathrm{L} \times \mathrm{T}$ interactions with greater genetic variability for earliness, yield and lint traits in upland cotton (Panhwar et al 2008; Samreen et al 2008; Ahuja et al 2009; Ashokkumar et al 2010; Karademir et al 2009; 2016; Sivia et al 2017; Khokhar et al 2018; Rajeev \& Patil 2018).

\subsection{Genetic variability among lines, testers and their $F_{1}$ hybrids}

Days to flowering varied from 57.67 (CIM-473) to 71.67 days (SLH-284) among lines, testers ranged from 56.00 (CIM-499) to 59.67 days (CIM-496)

Table 2- Mean squares for various traits of line $\mathbf{x}$ tester analysis in upland cotton

\begin{tabular}{|c|c|c|c|c|c|c|c|}
\hline Source of variation & d.f & $\begin{array}{l}\text { Days to } \\
\text { flowering }\end{array}$ & $\begin{array}{l}\text { Bolls } \\
\text { sympodia }^{-1}\end{array}$ & $\begin{array}{l}\text { Bolls } \\
\text { plant }^{-1} \\
\end{array}$ & $\begin{array}{l}\text { Boll } \\
\text { weight }\end{array}$ & $\begin{array}{l}\text { Seed cotton } \\
\text { yield plant }{ }^{-1}\end{array}$ & $G O T$ \\
\hline \multicolumn{8}{|c|}{ Analysis of variance } \\
\hline Replications & 2 & $16.97 \mathrm{~ns}$ & $0.39 \mathrm{~ns}$ & $53.02 *$ & $0.16 \mathrm{~ns}$ & 1052.24 & $4.07 \mathrm{~ns}$ \\
\hline Genotypes & 22 & $48.30 * *$ & $1.40 * *$ & $164.37 * *$ & $0.20 * *$ & $33303.31 * *$ & $12.47 *$ \\
\hline $\mathrm{CV} \%$ & & 4.49 & 16.10 & 13.15 & 9.45 & 30.60 & 7.00 \\
\hline \multicolumn{8}{|c|}{ ANOVA for Line $\times$ Tester analysis } \\
\hline Parents $(\mathrm{P})$ & 7 & 97.79 & 0.42 & 147.07 & 0.10 & 1732.10 & 8.46 \\
\hline P vs. C & 1 & 308.41 & 2.92 & 192.25 & 1.25 & 9875.92 & 85.29 \\
\hline Crosses $(\mathrm{C})$ & 14 & $24.45 * *$ & $1.79 * *$ & $171.03 * *$ & $0.18 \mathrm{~ns}$ & $7828.99 * *$ & $15.66^{* *}$ \\
\hline Lines & 4 & $37.08 * *$ & $2.15 \mathrm{~ns}$ & $156.86^{* *}$ & $0.13 \mathrm{~ns}$ & $5294.36^{* *}$ & $14.23 \mathrm{~ns}$ \\
\hline Testers & 2 & $11.09 \mathrm{~ns}$ & $0.97 * *$ & $242.89 * *$ & $0.05 \mathrm{~ns}$ & $9727.13 * *$ & $45.08 * *$ \\
\hline Lines $\times$ Testers & 8 & $21.48 * *$ & $1.81 * *$ & $160.15^{* *}$ & $0.24 * *$ & $8621.77 * *$ & $9.02 \mathrm{~ns}$ \\
\hline Error & 44 & 6.77 & 0.16 & 14.61 & 0.11 & 1044.36 & 5.80 \\
\hline$\sigma^{2} \mathrm{GCA}$ & - & 0.217 & -0.208 & 3.310 & -0.013 & -92.585 & 1.720 \\
\hline$\sigma^{2} \mathrm{SCA}$ & - & 4.903 & 0.55 & 48.513 & 0.043 & 2525.803 & 1.073 \\
\hline$\sigma^{2} \mathrm{GCA} / \sigma^{2} \mathrm{SCA}$ & - & 0.044 & -0.038 & 0.068 & -0.288 & -0.037 & 1.602 \\
\hline
\end{tabular}

*,**, significant at $\mathrm{P} \leq 0.05$ and $\mathrm{P} \leq 0.01 ;$ ns, non-significant 
while their $F_{1}$ hybrids varied from 53.33 to 65.33 days (Table 3 ). Overall, minimum days to flowering took by $\mathrm{F}_{1}$ hybrids CIM-506 $\times$ CIM-707 (53.33 days) and CIM-554 × CIM-496 (54.00 days) and were found at par with nine other $F_{1}$ hybrids and one tester (CIM-499) ranging from 54.33 to 57.33 days. Maximum days to flowering were observed in line SLH-284 (71.67 days), followed by its $\mathrm{F}_{1}$ hybrid SLH-284 × CIM-707 (65.33 days), two other lines i.e., CIM-446 (62.67 days) and CIM-506 (58.33 days) and one tester CIM-496 (59.67 days). Other genotypes showed medium days to flowering (57.67 to 58.33). Results further revealed that most of the $F_{1}$ hybrids showed early flowering and have more time for boll formation than lines and testers.

Table 3- Mean performance of parental cultivars and their $F_{1}$ hybrids for various traits in upland cotton

\begin{tabular}{|c|c|c|c|}
\hline $\begin{array}{l}\text { Parental cultivars/ } \\
F_{1} \text { hybrids }\end{array}$ & $\begin{array}{l}\text { Days to } \\
\text { flowering }\end{array}$ & $\begin{array}{c}\text { Bolls } \\
\text { sympodia }^{-1}\end{array}$ & $\begin{array}{l}\text { Bolls } \\
\text { plant }^{1} \\
\end{array}$ \\
\hline \multicolumn{4}{|c|}{ Lines } \\
\hline CIM-446 & 62.67 & 2.55 & 36.26 \\
\hline CIM-473 & 57.67 & 1.68 & 22.86 \\
\hline CIM-506 & 58.33 & 2.36 & 32.23 \\
\hline CIM-554 & 58.00 & 1.54 & 30.52 \\
\hline SLH-284 & 71.67 & 2.48 & 29.19 \\
\hline \multicolumn{4}{|c|}{ Testers } \\
\hline CIM-496 & 59.67 & 2.38 & 25.25 \\
\hline CIM-499 & 57.00 & 2.19 & 13.31 \\
\hline CIM-707 & 56.67 & 2.58 & 24.67 \\
\hline \multicolumn{4}{|c|}{$F_{l}$ hybrids (Lines $\times$ Testers $)$} \\
\hline CIM-446 × CIM-496 & 57.00 & 2.62 & 37.79 \\
\hline CIM-446 × CIM-499 & 54.33 & 1.86 & 23.54 \\
\hline CIM-446 × CIM-707 & 55.00 & 2.49 & 32.64 \\
\hline CIM-473 × CIM-496 & 55.33 & 3.50 & 45.33 \\
\hline CIM-473 × CIM-499 & 57.00 & 2.17 & 23.27 \\
\hline CIM-473 × CIM-707 & 56.67 & 2.91 & 37.97 \\
\hline CIM-506 × CIM-496 & 55.33 & 2.28 & 31.81 \\
\hline CIM-506 × CIM-499 & 58.33 & 1.76 & 20.95 \\
\hline CIM-506 × CIM-707 & 53.33 & 1.90 & 19.00 \\
\hline CIM-554 × CIM-496 & 54.00 & 3.38 & 30.51 \\
\hline CIM-554 × CIM-499 & 55.00 & 2.50 & 31.47 \\
\hline CIM-554 × CIM-707 & 57.67 & 2.07 & 30.75 \\
\hline SLH-284 × CIM-496 & 58.00 & 1.96 & 21.64 \\
\hline SLH-284 × CIM-499 & 57.33 & 3.32 & 29.52 \\
\hline SLH-284 × CIM-707 & 65.33 & 4.48 & 38.17 \\
\hline $\mathrm{LSD}_{0.05}$ & 4.283 & 0.686 & 6.289 \\
\hline
\end{tabular}

Bolls per sympodia ranged from 1.54 (CIM$554)$ to 2.55 (CIM-446) among lines, testers ranged from 2.19 (CIM-499) to 2.58 (CIM-707) while their $\mathrm{F}_{1}$ hybrids obtained 1.76 to 4.48 bolls per sympodia (Table 3). Overall, maximum bolls per sympodia were recorded for $\mathrm{F}_{1}$ hybrid SLH-284 × CIM-707 (4.48) followed by four other $\mathrm{F}_{1}$ hybrids (CIM$473 \times$ CIM-496, CIM-554 × CIM-496, SLH-284 $\times$ CIM-499, and CIM-473 $\times$ CIM-707) ranging from 2.91 to 3.50 . Minimum bolls per sympodia were achieved by line CIM-554 (1.54) and it was similar in performance with line (CIM-473) and six $F_{1}$ hybrids ranging from 1.76 to 2.17 . Other genotypes showed medium bolls per sympodia (2.19 to 2.28).

Bolls per plant ranged from 22.86 (CIM-473) to 36.26 (CIM-446) in lines, 13.31 (CIM-499) to 25.25 (CIM-496) in testers, and 19.00 (CIM-506 $\times$ CIM707) to 45.33 (CIM-473 $\times$ CIM-496) in $\mathrm{F}_{1}$ hybrids (Table 3). Among $\mathrm{F}_{1}$ hybrids, the highest number of bolls per plant was recorded for $\mathrm{F}_{1}$ hybrid CIM$473 \times$ CIM-496 (45.33). With at par performance, the promising hybrid was followed by four other $\mathrm{F}_{1}$ hybrids $($ SLH-284 $\times$ CIM-707, CIM-473 $\times$ CIM707, CIM-446 $\times$ CIM-496, CIM-446 $\times$ CIM-707) and two lines (CIM-446, CIM-506) ranging from 32.23 to 38.17 bolls per plant. Minimum bolls per plant (13.31) were obtained by tester (CIM-499) and was found same with $\mathrm{F}_{1}$ hybrid CIM-506 $\times$ CIM-707 (19.00). Other genotypes were found with medium number of bolls per plant.

Boll weight varied from 2.88 (CIM-554) to 3.53 $\mathrm{g}$ (CIM-446) in lines, 3.22 (CIM-707) to $3.33 \mathrm{~g}$ (CIM-499) in testers, while in $\mathrm{F}_{1}$ hybrids the range was 3.21 to $4.12 \mathrm{~g}$ (Table 4). Maximum boll weight (4.12 g) was observed in $\mathrm{F}_{1}$ hybrid CIM-473 × CIM499 and it was found same with five other $F_{1}$ hybrids (CIM-554 × CIM-707, CIM-446 × CIM-499, CIM$506 \times$ CIM-496, CIM-473 $\times$ CIM-496 and SLH-284 $\times$ CIM-707) ranging from 3.62 to $3.83 \mathrm{~g}$. Minimum boll weight was shown by line CIM-554 (2.88 g) and it was found at par with three testers i.e., CIM-707, CIM-496 and CIM-499. The remaining genotypes exhibited medium boll weight. 
Table 4- Mean performance of parental cultivars and their $F_{1}$ hybrids for various traits in upland cotton

\begin{tabular}{|c|c|c|c|}
\hline $\begin{array}{l}\text { Parental cultivars/ } \\
F_{1} \text { hybrids }\end{array}$ & $\begin{array}{c}\text { Boll } \\
\text { weight (g) }\end{array}$ & $\begin{array}{c}\text { Seed } \\
\text { cotton } \\
\text { yield } \\
\text { plant }^{-1}(\mathrm{~g})\end{array}$ & $\begin{array}{l}G O T \\
(\%)\end{array}$ \\
\hline \multicolumn{4}{|c|}{ Lines } \\
\hline CIM-446 & 3.53 & 125.90 & 33.28 \\
\hline CIM-473 & 3.28 & 79.96 & 35.59 \\
\hline CIM-506 & 3.27 & 109.60 & 37.42 \\
\hline CIM-554 & 2.88 & 101.40 & 32.73 \\
\hline SLH-284 & 3.36 & 101.20 & 32.55 \\
\hline \multicolumn{4}{|c|}{ Testers } \\
\hline CIM-496 & 3.26 & 103.80 & 35.68 \\
\hline CIM-499 & 3.33 & 46.77 & 34.49 \\
\hline CIM-707 & 3.22 & 81.51 & 35.66 \\
\hline \multicolumn{4}{|c|}{$F_{l}$ hybrids (Lines $\times$ Testers) } \\
\hline CIM-446 × CIM-496 & 3.47 & 136.39 & 37.12 \\
\hline CIM-446 × CIM-499 & 3.74 & 76.81 & 33.03 \\
\hline CIM-446 × CIM-707 & 3.30 & 119.50 & 28.91 \\
\hline CIM-473 × CIM-496 & 3.71 & 198.50 & 34.80 \\
\hline CIM-473 × CIM-499 & 4.12 & 84.54 & 33.44 \\
\hline CIM-473 × CIM-707 & 3.47 & 146.40 & 32.58 \\
\hline CIM-506 × CIM-496 & 3.73 & 126.90 & 34.08 \\
\hline CIM-506 × CIM-499 & 3.22 & 66.58 & 32.18 \\
\hline CIM-506 × CIM-707 & 3.51 & 70.92 & 33.59 \\
\hline CIM-554 × CIM-496 & 3.21 & 104.20 & 35.80 \\
\hline CIM-554 × CIM-499 & 3.50 & 118.20 & 37.32 \\
\hline CIM-554 × CIM-707 & 3.83 & 101.70 & 33.53 \\
\hline SLH-284 × CIM-496 & 3.36 & 73.70 & 37.33 \\
\hline SLH-284 × CIM-499 & 3.48 & 104.38 & 36.15 \\
\hline SLH-284 × CIM-707 & 3.62 & 150.00 & 33.28 \\
\hline $\mathrm{LSD}_{0.05}$ & 0.535 & 53.18 & 3.948 \\
\hline
\end{tabular}

For seed cotton yield per plant, the lines were in the range of 79.96 (CIM-473) to $125.90 \mathrm{~g}$ (CIM446), testers ranged from 46.77 (CIM-499) to 103.80 $\mathrm{g}(\mathrm{CIM}-496)$, while their $15 \mathrm{~F}_{1}$ hybrids ranged from 66.58 to $198.50 \mathrm{~g}$ (Table 4). Maximum seed cotton yield per plant was exhibited by $\mathrm{F}_{1}$ hybrid CIM-473 $\times$ CIM-496 (198.50 g). The said promising $\mathrm{F}_{1}$ hybrid was found equal in performance with two other $F_{1}$ cross combinations SLH-284 $\times$ CIM-707 (150.00 g) and CIM-473 $\times$ CIM-707 (146.40 g) for seed cotton yield per plant. Lowest seed cotton yield per plant was recorded in tester CIM-499 (46.77 g) and was found at par with one each line (CIM-473) and tester (CIM-707) and five $\mathrm{F}_{1}$ hybrids having involvement of almost above tester and line ranged from 66.58 to
84.54 g. However, other genotypes showed medium seed cotton yield per plant.

In case of lint $\%$, lines ranged from 32.55 (SLH$284)$ to $37.42 \%$ (CIM-506), testers ranged from 34.49 (CIM-499) to $35.68 \%$ (CIM-496), while their $\mathrm{F}_{1}$ cross combinations were in the range of 28.91 to $37.33 \%$ (Table 4). Maximum lint \% was recorded for line CIM-506 (37.42\%) and it was found at par with nine other $\mathrm{F}_{1}$ hybrids $(\mathrm{SLH}-284 \times \mathrm{CIM}-496$, CIM-554 × CIM-499, CIM-446 × CIM-496, SLH$284 \times$ CIM-499, CIM-554 $\times$ CIM-496, CIM-473 $\times$ CIM-496, CIM-506 $\times$ CIM-496, CIM-506 $\times$ CIM707 and CIM-554 $\times$ CIM-707) and two each lines and testers ranged from 35.53 to $37.42 \%$. Minimum lint \% was recorded for $\mathrm{F}_{1}$ hybrid CIM-446 $\times$ CIM$707(28.91 \%)$ and was found at par with two each lines (SLH-284 and CIM-554) and $\mathrm{F}_{1}$ hybrids (CIM$506 \times$ CIM-499, CIM-473 $\times$ CIM-707) ranged from 28.91 to $32.73 \%$. Other genotypes revealed medium values for lint $\%$.

Overall, $\quad F_{1}$ hybrid CIM-473 $\times$ CIM-496 manifested maximum values for bolls and seed cotton yield per plant, and was also found $2^{\text {nd }}$ scoring hybrid for boll weight and earliness. The $\mathrm{F}_{1}$ hybrid SLH-284 × CIM-707 showed maximum boll weight, and average values for yield related traits. The $\mathrm{F}_{1}$ hybrid CIM-446 × CIM-496 revealed maximum lint $\%$, and average values for yield contributing traits.

Using broad based genotype as a tester, the GCA of the lines is tested in the top cross method. The line $\times$ tester analysis is an extension of this method in which several testers are used (Kempthorne 1957; Singh \& Chaudhary 1985). The $\mathrm{L} \times \mathrm{T}$ design provides information about GCA and SCA of the lines and testers and their $\mathrm{F}_{1}$ hybrids, respectively and helpful in estimating the gene effects involved in the inheritance of various traits. Combining ability in general play key role in identifying the precious genotypes having specific cross combinations that can be used for hybrid program and for further selection in segregating generations. The $\mathrm{L} \times \mathrm{T}$ combining ability also work as principal method for improved production of crops in the form of $F_{1}$ hybrids and for screening the germplasm to 
determine the ability of the parental genotypes to be included in a breeding program based on their desirable GCA and SCA effects.

Yield is a highly complex character and is directly influenced by the various morphological and yield contributing traits. Therefore, knowledge about the genetic potential of different genotypes and inheritance of the various morpho-yield traits is indispensable for the breeders to tackle with the problems of low yield (Ahuja et al 2009; Khan et al 2017; Swetha et al 2018). In present results, the lines, testers and their interaction showed significant mean squares and greater genetic variations revealed by genotypes and their $\mathrm{F}_{1}$ hybrids for majority traits. Past findings elucidated significant mean squares for combining ability and genotypic variability in upland cotton populations (Samreen et al 2008; Ahuja et al 2009; Reddy et al 2017). Overall, the $\mathrm{F}_{1}$ hybrids i.e., CIM-473 $\times$ CIM-496, SLH-284 $\times$ CIM-707 and CIM-446 $\times$ CIM-496 revealed best performance for earliness, yield and lint traits. In past studies, significant variances were observed among $\mathrm{F}_{1}$ hybrids and their parental genotypes for bolls per plant, boll weight, seed cotton yield and lint \% in upland cotton (Khan et al 2009a, 2009b; Choudhary et al 2017). Similarly significant differences were noted among parental cultivars and their $\mathrm{F}_{1}$ hybrids for morphological and yield traits in upland cotton (Talpur et al 2016; Sivia et al 2017). Greater genetic variability indicated variable performance of the $\mathrm{F}_{1}$ populations and their parental lines for yield and lint traits and their vital role in managing seed cotton yield in upland cotton (Basal et al 2009; Ashokkumar et al 2010).

\subsection{Combining ability analysis}

Combining ability of the parental genotypes i.e., lines and testers (GCA) and their $\mathrm{F}_{1}$ hybrids (SCA) was studied through line $\times$ tester analysis to determine the ability of parent cultivars to combine their favorable genes during the hybridization and their transfer to the $F_{1}$ progenies. Two types of combining abilities i.e. GCA and SCA were studied, the GCA is due to additive gene effects whereas SCA is due to dominant and epistatic gene effects.
Female lines and male pollinators having maximum GCA effects were considered as the best general combiners for the said trait. However, the $\mathrm{F}_{1}$ hybrids having maximum SCA effects were treated as specified best hybrid combination for the concerned trait. The proportional contribution of lines, testers and their $\mathrm{L} \times \mathrm{T}$ interactions to total genetic variance for different traits was also studied which revealed the share of each component.

According to mean squares of combining ability, lines showed highly significant differences for days to flowering, bolls and seed cotton yield per plant, while non-significant for bolls per sympodia, boll weight and lint \% (Table 2). Testers also revealed highly significant differences for bolls per sympodia, bolls and seed cotton yield per plant and lint $\%$. The line $\times$ tester interactions showed highly significant differences for earliness, bolls per sympodia, bolls per plant, boll weight and seed cotton yield per plant. These results authenticated sufficient genetic variability among lines, testers, and $\mathrm{F}_{1}$ hybrids and allows further assessment through general combining ability.

For majority traits, the variances due to GCA were lower than SCA, suggesting the preponderance of non-additive gene action in controlling these variables (Table 2). Therefore, it appeared that inheritance of all the studied characters was controlled by non-additive gene effects. These results were supported by ratio of variance of GCA to SCA which was smaller than unity. Such type of gene action clearly indicated that selection of superior genotypes in terms of seed cotton yield and its contributing traits should be postponed to the later generations, where these traits can be improved by making selections among the recombinants within the segregating populations. However, for lint $\%$ the variance due to GCA was greater than SCA, and it was also confirmed by ratio of variance of GCA to SCA which was greater than unity.

The proportional contribution of $\mathrm{L} \times \mathrm{T}$ interactions was maximum to total sum of squares for days to flowering, bolls per sympodia, bolls per plant, boll weight and seed cotton yield per plant, 
followed by lines (Table 5). However, for lint \%, testers were the major contributors followed by their interaction with lines. These results showed that lines $\times$ testers interaction and lines brought much variation in the expression of the studied traits.

In proportional contribution of various components, $\mathrm{L} \times \mathrm{T}$ interaction contributed more to the total sum square of majority traits as compared to lines and testers, and provided room for further improvement through intensive selection. Significant differences of line $\mathrm{x}$ tester interaction was observed for all the traits under the study indicating the prevalence of non-additive variance (Reddy et al 2017; Sivia et al 2017; Prakash et al 2018). Earliness and yield related traits (days to flowering, bolls per sympodia, bolls per plant, boll weight and seed cotton yield per plant) were controlled by nonadditive genes by manifesting maximum SCA variances than GCA. Similarly, in various past studies the nonadditive type of gene action was observed for yield and yield contributing traits in upland cotton (Usharani et al 2016; Chattha et al 2018; Prakash et al 2018). Combining ability with nonadditive type of gene action for yield and fiber related traits were observed in upland cotton (Samreen et al 2008; Karademir et al 2009; Karademir \& Gener 2010). However, some studies revealed additive type of gene action for yield related traits in $F_{1}$ and $F_{2}$ populations of upland cotton (Lukonge et al 2007; Khan et al 2009a; Kumar et al 2017). The GCA variances were higher than SCA and revealed preponderance of additive gene action with enough genetic variability for most of the yield and fiber traits in Gossypium hirsutum L. (Esmail et al 2007). Such contradictions might be due to varied genetic background of breeding material and environmental conditions under which the experiments were conducted.

\subsubsection{General combining ability}

For days to flowering, the lines GCA ranged from -1.2 to 3.58 , while in testers the GCA ranged from -0.71 to 0.96 (Table 6). For earliness, negative GCA is desirable which encourage earliness and fewer days to flowering. Maximum negative GCA was revealed by lines CIM-446 (-1.20) and CIM-554 (-1.09). However, positive GCA was revealed by one each line SLH-284 (3.58) and tester CIM-707 (0.96), respectively. All other genotypes showed negative GCA effects. For bolls per sympodia, three out of five lines showed positive GCA values and ranged form 0.03 to 0.64 , while in testers the positive GCA values of 0.14 and 0.16 were obtained by genotypes CIM-496 and CIM-707, respectively. Overall, maximum GCA effects of 0.64 and 0.16 reveled by line SLH-284 and tester CIM-707, respectively for bolls per sympodia. For bolls per plant, lines GCA ranged from -6.37 (CIM-506) to 5.24 (CIM-473), testers GCA ranged from -4.54 to 3.13. Overall, highest positive GCA effects of 5.24 and 3.13 were exhibited by line CIM-473 and tester CIM-496, respectively for bolls per plant. Except two lines and one tester, all other genotypes showed positive GCA effects for bolls per plant.

In case of boll weight, lines GCA ranged from -0.07 to 0.22 while testers varied from -0.05 to 0.06 (Table 6). Except line CIM-473 (0.22) and tester CIM-499 (0.06), all other lines and testers

Table 5- Proportional contribution of lines, testers and their $\mathrm{L} \times \mathrm{T}$ interaction (\%) for various traits in upland cotton

\begin{tabular}{lcllllll}
\hline $\begin{array}{l}\text { Lines / Testers \& } \\
L \times \text { Tinteraction }\end{array}$ & d.f. & $\begin{array}{l}\text { Days to } \\
\text { flowering }\end{array}$ & $\begin{array}{l}\text { Bolls } \\
\text { sympodia }^{-1}\end{array}$ & $\begin{array}{l}\text { Bolls } \\
\text { plant }^{1}\end{array}$ & $\begin{array}{l}\text { Boll } \\
\text { weight }\end{array}$ & $\begin{array}{l}\text { Seed cotton } \\
\text { yield plant }\end{array}$ & GOT \\
\hline Lines & 4 & 43.33 & 34.41 & 26.20 & 21.21 & 19.32 & 25.96 \\
Testers & 2 & 6.48 & 7.74 & 20.29 & 3.83 & 17.75 & 41.12 \\
Lines $\times$ Testers & 8 & 50.19 & 57.85 & 53.51 & 74.96 & 62.93 & 32.92 \\
\hline
\end{tabular}


Table 6- General combining ability effects of lines and testers for various traits in upland cotton

\begin{tabular}{lcrrrrr}
\hline $\begin{array}{l}\text { Parental } \\
\text { cultivars }\end{array}$ & $\begin{array}{r}\text { Days to } \\
\text { flowering }\end{array}$ & $\begin{array}{r}\text { Bolls } \\
\text { sympodia }^{-1}\end{array}$ & $\begin{array}{r}\text { Bolls } \\
\text { plant }^{-1}\end{array}$ & $\begin{array}{r}\text { Boll } \\
\text { weight }\end{array}$ & $\begin{array}{r}\text { Seed cotton } \\
\text { yield plant }\end{array}$ & GOT \\
\hline CIM-446 & -1.2 & -0.29 & 1.03 & -0.05 & -7.96 & -1.19 \\
CIM-473 & -0.31 & 0.25 & 5.24 & 0.22 & 24.3 & -0.60 \\
CIM-506 & -0.98 & -0.63 & -6.37 & -0.06 & -30.74 & -0.93 \\
CIM-554 & -1.09 & 0.03 & 0.62 & -0.04 & -10.83 & 1.34 \\
SLH-284 & 3.58 & 0.64 & -0.51 & -0.07 & 25.24 & 1.38 \\
\hline & & \multicolumn{7}{c}{ Tines } \\
\hline CIM-496 & -0.71 & 0.14 & 3.13 & -0.05 & 9.07 & 1.62 \\
CIM-499 & -0.24 & -0.29 & -4.54 & 0.06 & -28.76 & 0.21 \\
CIM-707 & 0.96 & 0.16 & 1.41 & -0.01 & 19.69 & -1.83 \\
\hline
\end{tabular}

showed negative GCA effects for boll weight. For seed cotton yield, GCA ranged from -30.74 to 25.24 and -28.76 to 19.69 among lines and testers, respectively. However, two each lines SLH-284 (25.24) and CIM-473 (24.30) and testers CIM-707 (19.69) and CIM-496 (9.07) showed maximum positive GCA effects and excelled other parental cultivars for yield. In lint \%, two each lines SLH284 (1.38) and CIM-554 (1.34) and testers CIM496 (1.62) and CIM-499 (0.21) manifested highest positive GCA effects, while other lines and testers revealed negative GCA effects.

Overall, line SLH-284 revealed maximum positive GCA effects for bolls per sympodia, seed cotton yield and lint $\%$, and was found as best general combiner (Table 6). The maternal parent CIM-473 was found as $2^{\text {nd }}$ leading general combiner by having maximum positive GCA effects for bolls per plant, boll weight and desirable negative GCA values for earliness. In case of testers, cultivar CIM-496 was also appeared to be the best general pollinator for bolls per plant, lint $\%$ and desirable negative GCA value for days to flowering. The tester CIM-707 was $2^{\text {nd }}$ best general pollinator and revealed maximum positive GCA effects for bolls per sympodia and seed cotton yield per plant. Therefore, earliness and yield related traits could be further improved by identifying best general combiners and to use them hybridization program.
According to GCA effects, the lines SLH-284 and CIM-473 were found as best general combiners and exhibited highest positive GCA effects for maximum traits. In mean performance, cultivar SLH284 also expressed maximum mean values in its $\mathrm{F}_{1}$ derivatives by crossing with CIM-707 and CIM-496 for bolls per sympodia and lint \%, respectively. The line CIM-473 also showed prominent contribution through its promising $\mathrm{F}_{1}$ hybrids by crossing with CIM-496 for bolls and seed cotton yield per plant, and CIM-499 for boll weight. Results revealed that lines SLH-284 and CIM-473 could be safely used as best general combiners in breeding program for development of superior specific hybrids. $\mathrm{F}_{1}$ hybrids involve general combiners in combination with other cultivars showed highest mean performance for yield related traits in upland cotton (Khan et al 2009a; 2009b).

In case of testers, the pollinators CIM-496 and CIM-707 were appeared to be the best general combiners for having desirable GCA for majority traits. The tester CIM-496 manifested remarkable mean performance by crossing with lines CIM473 and SLH-284 for bolls and seed cotton yield per plant and lint \%. In average mean performance, the tester CIM-707 showed best recital as maternal parent by crossing with tester CIM-506 and revealed early maturity. In present studies, it was also concluded that high $\times$ high, high $\times$ low and low $\times$ high general combiners performed better in 
manifestation of specific $F_{1}$ hybrids for yield and lint traits. Previous studies also revealed that for getting good cross combination, at least one of the parents should have good GCA effect i.e., high $\times$ high, high $\times$ low and low $\times$ high GCA parents in cotton (Chinchane et al 2018). In past studies, in some cases high $\times$ low, low $\times$ high and high $\times$ high GCA parents showed best performance for majority traits in upland cotton (Panhwar et al 2008; Khan et al 2011, 2015; Karademir et al 2016). Therefore, the said traits can be further improved and strengthened by using the general combiners. In upland cotton, the parental genotypes with best GCA, used as a pollen parent produced better cross combinations, however, higher GCA of parents does not necessarily confer higher SCA, and the GCA and SCA were independent (Basal et al 2009; Khan et al 2009a; Sivia et al 2017).

\subsubsection{Specific combining ability}

For days to flowering, nine out of fifteen $\mathrm{F}_{1}$ hybrids revealed desirable negative SCA effects (ranging from -0.29 to -3.29 ) to boost early maturity (Table 7). However, six $F_{1}$ hybrids showed positive SCA effects ( 0.38 to 4.16$)$. Desirable maximum negative
SCA effects were possessed by $\mathrm{F}_{1}$ hybrids i.e., CIM-506 × CIM-707 (-3.29), SLH-284 × CIM-499 $(-2.64)$ and SLH- $284 \times$ CIM-496 (-1.51) and were found as best specific cross combinations for early maturity. At GCA level, the maternal line CIM-506 and testers CIM-499 and CIM-496 have manifested desirable negative GCA effects for days to flowering and played best response in presentation of desirable negative SCA effects in their $F_{1}$ hybrids through involvement as high $\times$ low and low $\times$ high general combiners.

For bolls per sympodia, nine $\mathrm{F}_{1}$ hybrids revealed positive SCA effects ranging from 0.07 to 0.60 , while negative SCA effects $(-0.11$ to -1.43$)$ revealed by six $\mathrm{F}_{1}$ hybrids (Table 7). However, $\mathrm{F}_{1}$ hybrids CIM-554 × CIM-496 (0.60), CIM-473 × CIM-496 (0.50) and SLH-284 $\times$ CIM-499 (0.63) enunciated maximum positive SCA effects and were established as best specific combiners for bolls per sympodia. The involvement of best general combiners SLH284 and CIM-473 revealed the $F_{1}$ hybrids with promising SCA values. Therefore, low $\times$ high, high $\times$ high and high $\times$ low general combiners revealed promising SCA for bolls per sympodia.

Table 7- Specific combining ability effects of lines $x$ testers for various traits in upland cotton

\begin{tabular}{|c|c|c|c|c|c|c|}
\hline$F_{1}$ hybrids & $\begin{array}{r}\text { Days to } \\
\text { Flowering }\end{array}$ & $\begin{array}{r}\text { Bolls } \\
\text { sympodia }^{-1}\end{array}$ & $\begin{array}{r}\text { Bolls } \\
\text { plant }^{-1}\end{array}$ & $\begin{array}{r}\text { Boll } \\
\text { weight }\end{array}$ & $\begin{array}{l}\text { Seed cotton } \\
\text { yield plant }\end{array}$ & GOT \\
\hline CIM-446 × CIM-496 & 2.27 & 0.16 & 3.34 & 0.02 & 16.42 & 2.48 \\
\hline CIM-446 × CIM-499 & -0.87 & -0.17 & -3.24 & 0.18 & -5.33 & -0.20 \\
\hline CIM-446 × CIM-707 & -1.40 & 0.01 & -0.10 & -0.20 & -11.09 & -2.28 \\
\hline CIM-473 × CIM-496 & -0.29 & 0.50 & 6.68 & 0.00 & 46.29 & -0.42 \\
\hline CIM-473 × CIM-499 & 0.91 & -0.40 & -7.71 & 0.29 & -29.86 & -0.38 \\
\hline CIM-473 × CIM-707 & -0.62 & -0.11 & 1.03 & -0.29 & -16.43 & 0.80 \\
\hline CIM-506 × CIM-496 & 0.38 & 0.17 & 4.76 & 0.30 & 29.67 & -0.82 \\
\hline CIM-506 × CIM-499 & 2.91 & 0.07 & 1.57 & -0.33 & 7.22 & -1.32 \\
\hline CIM-506 × CIM-707 & -3.29 & -0.23 & -6.34 & 0.03 & -36.89 & 2.14 \\
\hline CIM-554 × CIM-496 & -0.84 & 0.60 & -3.53 & -0.25 & -12.90 & -1.37 \\
\hline CIM-554 × CIM-499 & -0.31 & 0.14 & 5.10 & -0.07 & 38.93 & 1.56 \\
\hline CIM-554 × CIM-707 & 1.16 & -0.74 & -1.57 & 0.32 & -26.03 & -0.19 \\
\hline SLH-284 × CIM-496 & -1.51 & -1.43 & -11.26 & -0.07 & -79.47 & 0.12 \\
\hline SLH-284 × CIM-499 & -2.64 & 0.36 & 4.28 & -0.06 & -10.96 & 0.35 \\
\hline SLH-284 × CIM-707 & 4.16 & 1.07 & 6.98 & 0.14 & 90.43 & -0.47 \\
\hline
\end{tabular}


It is obvious from Table 7 that eight $\mathrm{F}_{1}$ hybrids exhibited positive SCA effects (1.03 to 6.98) for bolls per plant, while remaining seven $\mathrm{F}_{1}$ hybrids exhibited negative SCA effects $(-0.10$ to -11.26$)$. Maximum positive SCA effects were possessed by $\mathrm{F}_{1}$ cross combinations i.e. SLH-284 $\times$ CIM-707 (6.98), CIM-473 $\times$ CIM-496 (6.68) and CIM-554 $\times$ CIM-499 (5.10) and were found as best specific combiners for bolls per plant. The line CIM-473 and testers CIM-496 and CIM-707 were already announced as best general combiners and the same stability performance have shown by these lines and pollinators as low $\times$ high, high $\times$ high and high $\times$ low general combiners.

For boll weight, eight $\mathrm{F}_{1}$ hybrids exhibited positive SCA effects ranged from 0.02 to 0.32 , while seven $\mathrm{F}_{1}$ hybrids showed negative SCA values (-0.06 to -0.33 ) (Table 7). Highest SCA effects owned by $\mathrm{F}_{1}$ hybrids CIM-554 $\times$ CIM-707 (0.32), CIM-506 $\times$ CIM-496 (0.30) and CIM-473 × CIM-499 (0.29). For the former two hybrids the parental genotypes i.e., CIM-554, CIM-707, CIM-506 and CIM-496 have shown negative GCA effects, whereas in later hybrid the genotypes CIM-473 and CIM-499 have highest GCA effects. Therefore, low $\times$ low and high $\times$ high GCA parents were involved in producing $\mathrm{F}_{1}$ hybrids with desirable SCA effects for boll weight.

For seed cotton yield per plant, positive SCA effects were manifested by six $F_{1}$ hybrids ranged from 7.22 to 90.43 , while nine $F_{1}$ hybrids revealed negative SCA effects (-5.33 to -79.47) (Table 7). However, the utmost desirable SCA effects were shown by $\mathrm{F}_{1}$ hybrids i.e., SLH-284 $\times$ CIM-707 (90.67), CIM-473 × CIM-496 (46.29), CIM-554 × CIM-499 (38.93) and CIM-506 × CIM-496 (29.67) for seed cotton yield per plant. Results further revealed that high $\times$ high, high $\times$ low, low $\times$ high and low $\times$ low GCA parental genotypes were involved in manifestation of $F_{1}$ hybrids with desirable SCA effects for seed cotton yield.

For lint $\%$, six $\mathrm{F}_{1}$ hybrids revealed positive SCA with range of 0.12 to 2.48 , while negative SCA values ( -0.19 to -2.28$)$ were noted in nine $\mathrm{F}_{1}$ hybrids (Table 7). However, $\mathrm{F}_{1}$ hybrids CIM-446 $\times$ CIM-
496 (2.48), CIM-506 × CIM-707 (2.14) and CIM$554 \times$ CIM-499 (1.56) were found as best specific combiners by having maximum SCA effects and excelled all other $\mathrm{F}_{1}$ hybrids for lint $\%$. In above $\mathrm{F}_{1}$ hybrids, the lines (CIM-446, CIM-506 and CIM554), and testers (CIM-496, CIM-707 and CIM499) used were having low GCA effects except line CIM-554 and tester CIM-496 which has maximum positive GCA effects.

Overall, the $\mathrm{F}_{1}$ hybrid SLH-284 $\times$ CIM-707 revealed desirable SCA effects for bolls per sympodia, bolls per plant and seed cotton yield per plant (Table 7). The $2^{\text {nd }}$ best scoring $F_{1}$ hybrids were CIM-473 × CIM-496 (bolls and seed cotton yield per plant), CIM-506 $\times$ CIM-707 (earliness and lint $\%$ ), CIM-554 × CIM-496 (bolls per sympodia), CIM-554 $\times$ CIM-707 (boll weight) and CIM-446 $\times$ CIM-496 (lint \%) which showed desirable SCA effects for earliness and yield traits.

In present studies, $\mathrm{F}_{1}$ hybrid SLH-284 $\times$ CIM707 was the leading cross combination for having desirable SCA effects for majority of the traits and involve high $\times$ high GCA parents. The high $\times$ high general combiners were involved in the expression of majority morphological and yield related traits in Gossypium hirsutum L. (Karademir et al 2009; Khan et al 2009b). Present studies also proved that parental cultivar with best GCA and its utilization as one of the parents produced superior $\mathrm{F}_{1}$ hybrids. However, in some previous studies, it was concluded that both parents with higher GCA were found to produce high yielding $F_{1}$ hybrids in upland cotton (Lukonge et al 2007; Abro et al 2009; Basal et al 2009). The promising $F_{1}$ hybrids always involve at least one parent with high/average GCA for a particular trait in cotton. Some lines and testers by having desirable GCA effects performed better and provided maximum genetic variability in $F_{1}$ hybrids. However, in contradiction, parental genotypes performance in their specific $F_{1}$ hybrids exhibited that it is always not necessary that general combiners will provide best $F_{1}$ hybrids, however, parents with low GCA may have the potential to produce promising hybrids (Karademir \& Gener 2010; Talpur et al 2016; Reddy et al 2017). 
The $2^{\text {nd }}$ best scoring $\mathrm{F}_{1}$ hybrids were CIM- $473 \times$ CIM-496 (bolls and seed cotton yield per plant) and CIM-506 × CIM-707 (earliness and lint \%) which showed highest SCA effects. In the remaining populations, $\mathrm{F}_{1}$ hybrids CIM-554 $\times$ CIM-496 for bolls per sympodia, CIM-554 $\times$ CIM-707 for boll weight and CIM-446 $\times$ CIM-496 for lint $\%$, showed desirable SCA effects. Therefore, these $\mathrm{F}_{1}$ hybrids could be further explored in segregating generations for improvement in their genetic potential for said traits. In these $\mathrm{F}_{1}$ hybrids, lines (SLH-284 and CIM473) and testers (CIM-707 and CIM-496) were the best general combiners. General combiners involvement itself (high $\times$ high) and also as high $\times$ low and low $\times$ high GCA parents manifested desirable SCA for majority yield traits. However, the SCA effects authenticated that best specific combinations were having high $\times$ low and low $\times$ high GCA parents and performed well in SCA determination, with outstanding mean performance and heterosis (Abro et al 2009; Basal et al 2009; Karademir et al 2009). Significant SCA differences were determined among $\mathrm{F}_{1}$ hybrids for morphoyield and fiber quality traits (Lukonge et al 2007; Ahuja et al 2009).

\subsection{Heritability and correlation}

Heritability is the proportion of phenotypic variation in a population that is attributable to genetic variation among individuals. For each trait, genetic, environmental and phenotypic variation, heritability broad sense (bs) and expected response to selection were estimated from mean squares (Table 8). Overall, heritability ranged from 0.45 to 0.91 for various traits. For days to flowering, the genetic variance (13.84) was two times greater than environmental variance (6.77). Heritability (bs) for said trait was also high (0.86) with genetic advance of 4.83 days and its value as percent of population mean was $8.34 \%$. High broad sense heritability $(0.89)$ and moderate expected response to selection $(0.82 \#$, $33.60 \%$ ) were recorded for bolls per sympodia. For bolls per plant, the genetic variance (49.92) was almost three times greater than environmental variance (14.60) with high broad sense heritability (0.91) and selection response values of 9.44\# and $32.48 \%$. Heritability (bs) for boll weight was moderate (0.45) with genetic gain values of $0.16 \mathrm{~g}$ and $4.71 \%$. In seed cotton yield, the genetic variance (2259.95) was two times greater than environmental variance (1044.36) with high broad sense heritability (0.68) and selection response values $(31.77 \mathrm{~g}$, $30.09 \%$ ). For lint $\%$, heritability (bs) was 0.54 and expected response to selection was 1.54 its value as percent of population mean was $4.48 \%$. Correlation of seed cotton yield was highly significant positive with bolls per sympodia $(r=603)$ and bolls per plant $(\mathrm{r}=0.720)$, nonsignificant positive with days to flowering $(\mathrm{r}=0.202)$ and boll weight $(\mathrm{r}=0.186)$ (Table 9). However, correlation of lint $\%(r=-0.060)$ was negative and nonsignificant with seed cotton yield. Overall, high heritability with appreciable genetic advance and positive association of yield with yield components and earliness revealed that yield traits could be improved through selection in early segregating populations.

Table 8- Genotypic (Vg), environmental (Ve) and phenotypic (Vp) coefficient of variance, heritability (bs), genetic advance (G.A) and its percentages

\begin{tabular}{|c|c|c|c|c|c|c|}
\hline Parameters & $V g$ & Ve & $V p$ & Heritability (bs) & G.A. & G.A. $(\%)$ \\
\hline Days to flowering & 13.84 & 6.77 & 16.10 & 0.86 & 4.83 days & 8.34 \\
\hline Bolls sympodia $^{-1}$ & 0.39 & 0.15 & 0.44 & 0.89 & $0.82 \#$ & 33.60 \\
\hline Bolls plant $^{-1}$ & 49.92 & 14.61 & 54.79 & 0.91 & $9.44 \#$ & 32.48 \\
\hline Boll weight & 0.03 & 0.11 & 0.06 & 0.45 & $0.16 \mathrm{~g}$ & 4.71 \\
\hline Seed cotton yield plant $t^{-1}$ & 753.01 & 1044.36 & 1101.13 & 0.68 & $31.77 \mathrm{~g}$ & 30.09 \\
\hline Lint $\%$ & 2.24 & 5.76 & 4.16 & 0.54 & $1.54 \%$ & 4.48 \\
\hline
\end{tabular}


Table 9- Correlation of various traits with seed cotton yield in upland cotton

\begin{tabular}{lcc}
\hline Parameters & $\begin{array}{c}\text { Correlation }(r) \text { with } \\
\text { seed cotton } \\
\text { yield plant }\end{array}$ & $\begin{array}{c}\text { Standard } \\
\text { error }\end{array}$ \\
\hline Days to flowering & 0.202 & 0.010 \\
Bolls sympodia $^{-1}$ & $0.603 * *$ & 0.001 \\
Bolls plant $^{-1}$ & $0.720^{* *}$ & 0.013 \\
Boll weight & 0.186 & 0.001 \\
Lint \% & -0.060 & 0.006 \\
\hline
\end{tabular}

Heritability and genetic potential studies of various cotton cultivars in form of their expression for various yield traits are earnestly needed for selection of parental lines for successful breeding program (Hague et al 2008). Present findings revealed high heritability (bs) with appreciable genetic advance for almost all the traits. Substantial genetic variances and high heritability estimates implied that characters could be improved through selection in segregating populations in early generations. Higher heritability and genetic gain is an indication of additiveness with partial dominance type of gene action suggesting the feasibility of selection in the early generations (Khan et al 2009a). However, bolls per plant and boll weight exhibited moderate to high heritability and low genetic gain with over dominance type of gene action thereby revealing that selection might be useful if delayed (Khan et al 2009b). In present studies, high genetic variance and heritability revealed that there are better chances of improvement by getting early maturity in some genotypes. Majority traits revealed positive association with seed cotton yield except lint $\%$. Basal et al (2009) mentioned that fiber quality traits were negatively associated with the most basic within-boll lint yield components. Both at genotypic and phenotypic levels, seed cotton yield exhibited significant positive association with bolls, seed cotton weight per boll, plant height, monopodia/ plant and fiber strength revealed that any selection among correlated traits might lead to improvement in seed cotton yield, while with other fiber traits the correlation was negative (Ahuja et al 2009). Correlation of seed cotton yield was significantly positive with yield related traits, however, the association was negative with lint \% (Khan et al 2011; 2015).

\section{Conclusions}

Seed cotton yield and its contributing traits were controlled non-additively, and hence, the selection might be effective if delayed. Lines (SLH-284, CIM-473) and pollinators (CIM-707, CIM496) were leading general combiners, and their involvement in $\mathrm{F}_{1}$ hybrids (CIM-473 $\times$ CIM-496, SLH-284 $\times$ CIM-707 and CIM-446 $\times$ CIM-496) showed best performance for earliness, yield and lint traits. Therefore, these promising hybrids may be preferred for hybrid crop development.

\section{References}

Abro S, Kandhro M M, Laghari S, Arain M A \& Deho Z A (2009). Combining ability and heterosis for yield contribution traits in upland cotton (G. hirsutum L.). Pakistan Journal of Botany 41: 1769-1774

Ahuja S L, Dhayal L S \& Monga D (2009). Performance of upland colored cotton germplasm lines in line $\times$ tester crosses. Euphytica 169: 303-312

Ashokkumar K, Ravikesavan R \& Prince K S J (2010). Combining ability estimates for yield and fiber quality traits in line $\times$ tester crosses of upland cotton. International Journal of Biology 2: 179-183

Basal H, Unay A, Canavar O \& Yavas I (2009). Combining ability for fiber quality parameters and within-boll yield components in intraspecific and interspecific cotton populations. Spanish Journal of Agricultural Research 7: 364-374

Bilwal B B, Vadodariya K V, Rajkumar B K, Lahane G R \& Shihare N D (2018). Combining ability analysis for seed cotton yield and its component traits in cotton (G. hirsutum L.). International Journal of Current Microbiology and Applied Sciences 7: 3005-3010

Burton G W (1951). Quantitative inheritance in pearl millet (Pennisetum glaucum). Agronomy Journal 43: 409-417

Chattha W S, Shakeel A, Malik T A, Saleem M F, Akram H M, Yaseen M \& Naeem M (2018). Combining ability analysis of yield and fiber quality traits under normal and water deficit condition in G. hirsutum L. 
The Journal of Animal \& Plant Sciences 28: 10621067

Chinchane V N, Patil V S \& Ingole D G (2018). Combining ability studies for yield and its components in desi cotton ( $G$. arboreum L.). International Journal of Current Microbiology and Applied Sciences. Special Issue-6: 1368-1372

Choudhary R, Solanki B G, Gahtyari N C, Paul T \& Singh A K (2017). Genetic effects of combining ability studies for quantitative traits in intra- and interspecific crosses of diploid cotton ( $G$. arboreum and $G$. herbaceum). Electronic Journal of Plant Breeding 8: 10-19

Economic Survey of Pakistan (2017-2018). Finance Division, Government of Pakistan, Islamabad Pakistan (www.finance.gov.pk)

Esmail R M (2007). Genetic analysis of yield and its contributing traits in two intra-specific cotton crosses. Journal of Applied Sciences Research 3: 2075-2080

Griffing B (1956). Concept of GCA and SCA in relation to diallel system. Australian Journal of Biological Sciences 9: 463-493

Hague S S, John G R \& Randal B K (2008). Combining ability of upland cotton, G. hirsutum L., with traits associated with sticky fiber. Euphytica 164: 175-179

Hayter A J (1986). The maximum family-wise error rate of Fisher's least significant difference test. Journal of the American Statistical Association 81: 1001-1004

Karademir C, Emine K, Remzi E \& Oktay G (2009). Combining ability estimates and heterosis for yield and fiber quality of cotton in line $\times$ tester design. Notulae Botanicae Horti Agrobotanici Cluj-Napoca 37: 228-233

Karademir E \& Gener O (2010). Combining ability and heterosis for yield and fiber quality properties in cotton ( $G$. hirsutum L.) obtained by half diallel mating design. Notulae Botanicae Horti Agrobotanici Cluj-Napoca 38: 222-227

Karademir E, Karademir C \& Basal H (2016). Combining ability and line $\mathrm{x}$ tester analysis on heat tolerance in cotton (G. hirsutum L.). Indian Journal of Natural Sciences 6: 10515-10525

Kempthorne O (1957). Introduction to Genetic Statistics. New York, John Valley and Sons Inc., London, Chapman \& Hall, Limited

Khan A M, Fiaz S, Bashir I, Ali S, Afzal M, Kettener K, Mahmood N \& Manzoor M (2017). Estimation of genetic effects controlling different plant traits in cotton ( $G$. hirsutum L.) under $\mathrm{CLCuV}$ epidemic condition. Cercetări Agronomice în Moldova 1: 47-56

Khan N U, Hassan G, Kumbhar M B, Marwat K B, Khan M A, Parveen A, Aiman U \& Saeed M (2009a). Combining ability analysis to identify suitable parents for heterosis in seed cotton yield, its components and lint \% in upland cotton. Industrial Crops and Products 29: 108-115

Khan N U, Hassan G, Marwat K B, Kumbhar B, Khan I, Soomro Z A, Baloch M J \& Khan M Z (2009b). Legacy study of cottonseed traits in upland cotton using Griffing's combining ability model. Pakistan Journal of Botany 41: 131-142

Khan S A, Khan N U, Mohammad F, Ahmad M, Khan I A, Bibi Z \& Khan I U (2011). Combining ability analysis in intraspecific $\mathrm{F}_{1}$ diallel cross of upland cotton. Pakistan Journal of Botany 43: 1719-1723

Khan S A, Khan N U, Gul R, Bibi Z, Khan I U, Gul S, Ali S \& Baloch M (2015). Combining ability studies for yield and fiber traits in upland cotton. The Journal of Animal and Plant Sciences 25: 698-707

Khokhar E S, Shakeel A, Maqbool M A, Abuzar M K, Zareen S, Aamir S S \& Asadullah M (2018). Studying combining ability and heterosis in different cotton (G. hirsutum L.) genotypes for yield and yield contributing traits. Pakistan Journal of Agricultural Research 31: 55-68

Kumar A, Nirania K S, Chhavikant \& Bankar A H (2017). Combining ability for seed cotton yield and attributing traits in American cotton (G. hirsutum L.). Journal of Pharmacognosy and Phytochemistry 6: 376-378

Lokesh K M, Borgaonkar S B, Deosarkar D B \& Chinchane V N (2018). Study of combining ability analysis for seed cotton yield, yield contributing and fiber quality traits in desi cotton ( $G$. arboreum L.). International Journal of Plant Sciences (Muzaffarnagar) 13: 1-6

Lukonge E P, Labuschagne M T \& Herselman L (2007). Combining ability for yield and fiber characteristics in Tanzanian cotton germplasm. Euphytica 161: 383389

Panhwar S A, Baloch M J, Jatoi W A, Veesar N F \& Majeedano M S (2008). Combining ability estimation from line $\times$ tester mating design in upland cotton. Proceedings, Pakistan Academy of Sciences 45: 69-74

PBS (2017-2018). Pakistan Economic Survey, Pakistan Bureau of Statistics (PBS), Ministry of Economic 
Affairs and Statistics, Govt. of Pakistan, Islamabad, Pakistan

Prakash G, Korekar S L \& Mankare S (2018). Combining ability analysis in $\mathrm{Bt}$ cotton (G. hirsutum L.) to harness high yield under contrasting planting densities through heterosis breeding. International Journal of Current Microbiology and Applied Sciences 7: 17651774

Rajeev S \& Patil S S (2018). Combining ability studies in cotton interspecific heterotic group hybrids $(G$. hirsutum x G. barbadense) for seed cotton yield and its components. International Journal of Current Microbiology and Applied Sciences 7: 3955-3963

Reddy K B, Reddy V C, Ahmed M L, Naidu T C M \& Srinivasarao V (2017). Combining ability analysis for seed cotton yield and quality traits in upland cotton (G. hirsutum L.). Electronic Journal of Plant Breeding 8: 142-152

Roy U, Paloti M C, Patil R S \& Katageri S (2018). Combining ability analysis for yield and yield attributing traits in interspecific (G. hirsutum L. $\times G$. barabdense L.) hybrids of cotton. Electronic Journal of Plant Breeding 9: 458-464

Samreen K, Baloch M J, Soomro Z A, Kumbhar M B, Khan N U, Kumboh N, Jatoi W A \& Veesar N F (2008). Estimating combining ability through line $\times$ tester analysis in upland cotton $(G$. hirsutum L.). Sarhad Journal of Agriculture 24: 581-586

Singh R K \& Chaudhary B D (1985). Biometrical methods in quantitative genetic analysis. Kalyani Publishers Ludhiana and New Delhi, India
Sivia S S, Siwach S S, Sangwan O, Lingaraja L \& Vekariya R D (2017). Combining ability estimates for yield traits in line $\times$ tester crosses of upland cotton (G. hirsutum L.). International Journal of Pure and Applied Bioscience 5: 464-474

Sprague G F \& Tatum L A (1942). General and specific combining ability in single crosses of corn. Journal of American Society of Agronomy 34: 923-932

Steel R G D, Torrie H \& Dickey D A (1997). Principles and procedures of statistics - A Biometrical Approach. $3^{\text {rd }}$ Ed. McGraw Hill, Inc. New York

Swetha S, Nidagundi J M, Diwan J R, Lokesha R, Hosmani A C \& Hadimani A (2018). Combining ability studies in cotton ( $G$. barbadense L.). Journal of Pharmacognosy and Phytochemistry 7: 638-642

Talpur M Y M, Memon S, Memon S, Mari S N, Laghari S, Soomro Z A, Arain S, Dev W, Abro A A \& Abro S (2016). Combining ability estimates from line $\mathrm{x}$ tester mating design in upland cotton. Journal of Basic and Applied Sciences 12: 378-382

Thombre K S, Deosarkar D B, Chinchane V N \& Borgaonkar S B (2018). Study of combining ability analysis for seed cotton yield, yield contributing and fiber quality traits in desi cotton (G. arboreum L.). IJPS International Journal of Plant Sciences 13: 3541

Usharani C V, Manjula S M \& Patil S S (2016). Estimating combining ability through line $\times$ tester analysis in upland cotton. Research in Environment and Life Sciences 9: 628-633 